\title{
A study of single nucleotide polymorphism of leptin gene effect on serum copper, zinc and iron concentrations in Czech Pied bulls
}

\author{
Aleš Pavlík ${ }^{1}$, Petr Sláma ${ }^{1}$,Aleš Knoll ${ }^{1}$, Aleš Dufek ${ }^{3}$, Petr Škarpa ${ }^{4}$, Jan Šubrt² \\ ${ }^{1}$ Mendel University in Brno, Department of Animal Morphology, Physiology and Genetics, \\ Brno, Czech Republic \\ ${ }^{2}$ Mendel University in Brno, Department of Animal Breeding, Brno, Czech Republic \\ ${ }^{3}$ Agriresearch Rapotin Ltd., Vikýřovice, Czech Republic \\ ${ }^{4}$ Mendel University in Brno, Department of Agrochemistry, Soil Science, Microbiology and Plant Nutrition, \\ Brno, Czech Republic \\ Received March 15, 2013 \\ Accepted June 19, 2013
}

\begin{abstract}
Leptin, the product of the $o b$ gene, is secreted mainly in adipose tissue. Due to the associations between plasma leptin concentrations and body fat, leptin could be used as an indicator for the in vivo evaluation of carcass composition in breeding programs. Previous studies showed relation between leptin concentrations and some trace elements, suggesting that they might be mediators of leptin production. The present study was designed to evaluate the effect of single nucleotide polymorphism of the leptin gene on concentration of trace elements in the serum of 58 Czech Pied bulls. Three experimental groups of bulls were formed depending on different leptin genotypes: group $C C(\mathrm{n}=28)$, group $C T(\mathrm{n}=21)$ and group $T T(\mathrm{n}=9)$. In all groups, the age (at a mean age of 240 days) and the body weight (mean $291 \pm 11 \mathrm{~kg}$ ) difference among the chosen animals was non-significant. Blood samples of all bulls in experimental groups were collected from vena jugularis externa between 8.00 and $9.30 \mathrm{~h}$. Concentrations of copper, zinc and iron in the serum of animals were measured. Significantly lower $(P<0.05)$ zinc concentrations were recorded in bulls of TT group $\left(13.21 \pm 1.81 \mu \mathrm{mol} \cdot \mathrm{l}^{-1}\right)$ compared to $C C\left(20.09 \pm 1.11 \mu \mathrm{mol} \cdot \mathrm{l}^{-1}\right)$ and $C T$ group $\left(19.67 \pm 1.45 \mu \mathrm{mol} \cdot \mathrm{l}^{-1}\right)$. In case of copper and iron concentrations in serum of animals, no differences were recorded between the tested groups. This is the first study of its kind in Czech Pied cattle. Based on our results, we may assume that zinc plays some role in the metabolism of adipose tissue, havings an effect on beef quality.
\end{abstract}

Cattle, trace elements, blood, adipose tissue

The systemic leptin concentrations are strongly associated with mRNA concentrations in subcutaneous adipose tissue and cellularity (Delavaud et al. 2002). The leptin gene has been mapped to bovine chromosome 4 (Stone et al. 1996). Single nucleotide polymorphisms (SNP) in the leptin gene (cytosine to thymine transition in exon 2, that encoded amino acid change of arginine to cysteine) have been associated with serum leptin concentration, feed intake and milk yield (Liefers et al. 2002). Allelic variation in the leptin gene has also been associated with increased fat deposition in beef cattle (Nkrumah et al. 2004) and variation in marbling (Le et al. 2013). The $T$ allele was associated with fatter carcasses and the $C$ allele with leaner carcasses (Buchanan et al. 2002).

Trace elements such as copper $(\mathrm{Cu})$, iron $(\mathrm{Fe})$ and zinc $(\mathrm{Zn})$ are essential nutrients both for humans and animals, and are needed in very small amounts for many physiological functions, including immune and antioxidant function, growth and reproduction. Due to having the same biological effects, it has been hypothesized that serum leptin may be associated with the trace elements (Olusi et al. 2003). However, there is very little information available about the association of serum leptin with trace elements in healthy populations of domestic animals.

Address for correspondence:

Aleš Pavlík

Department of Animal Morphology, Physiology and Genetics

Mendel University in Brno

Zemědělská 1, 61300 Brno

Czech Republic

Phone: +420 545133148

E-mail: pavlik@mendelu.cz:

http://actavet.vfu.cz/ 
The aim of the present study was to test the hypothesis that leptin gene single nucleotide polymorphism has an effect on the concentration of copper, zinc and iron in the serum of Czech Pied bulls.

\section{Materials and Methods}

Animals and breeding conditions

The experiment was performed on 58 Czech Pied Cattle bulls $240 \pm 9$ days of age, mean weight $291 \pm 11 \mathrm{~kg}$, body condition scoring (BCS) - 3, kept on deep litter in boxes. Three experimental groups of these animals were created depending on different leptin genotypes: group $C C(\mathrm{n}=28)$, group $C T(\mathrm{n}=21)$ and group $T T(\mathrm{n}=9)$. In all groups, the age and body weight difference among the chosen animals was non-significant. The feeding ration was based on corn silage. The feeding rations components and the content of standard nutrients in the feeding ration are presented in Table 1.

Table 1. Components and nutrients composition of the diets of 240 days old Czech Pied bulls divided into 3 groups depending on leptin single nucleotide polymorphism (TT, CT, CC).

\begin{tabular}{|c|c|}
\hline Component/nutrient & Value \\
\hline Corn silage $\left(\mathrm{kg} \cdot \mathrm{day}^{-1}\right)$ & 15 \\
\hline Clover haylage $\left(\mathrm{kg} \cdot \mathrm{day}^{-1}\right)$ & 5 \\
\hline $\mathrm{CCM}\left(\mathrm{kg} \cdot \mathrm{day}^{-1}\right)$ & 1.5 \\
\hline Hay $\left(\mathrm{kg} \cdot \mathrm{day}^{-1}\right)$ & 0.5 \\
\hline Straw $\left(\mathrm{kg} \cdot \mathrm{day}^{-1}\right)$ & 0.5 \\
\hline Wheat meal $\left(\mathrm{kg} \cdot \mathrm{day}^{-1}\right)$ & 1.7 \\
\hline Maize meal $\left(\mathrm{kg} \cdot \mathrm{day}^{-1}\right)$ & 0.6 \\
\hline Rapeseed meal $\left(\mathrm{kg} \cdot \mathrm{day}^{-1}\right)$ & 0.5 \\
\hline Limestone powder $\left(\mathrm{kg} \cdot \mathrm{day}^{-1}\right)$ & 0.8 \\
\hline Feed salt $\left(\mathrm{kg} \cdot \mathrm{day}^{-1}\right)$ & 0.05 \\
\hline Mineral-vitamin feedstuffs for cattle & \\
\hline (VVS, Czech Republic) $\left(\mathrm{kg} \cdot\right.$ day $\left.^{-1}\right)$ & 0.18 \\
\hline Crude protein $\left(\mathrm{g} \cdot \mathrm{kg}^{-1}\right)$ & 125.5 \\
\hline Crude fiber $\left(\mathrm{g} \cdot \mathrm{kg}^{-1}\right)$ & 173.6 \\
\hline Net energy $\left(\mathrm{MJ} \cdot \mathrm{kg}^{-1}\right)$ & 6.1 \\
\hline 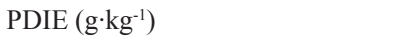 & 80.6 \\
\hline PDIN $\left(g \cdot \mathrm{kg}^{-1}\right)$ & 82.3 \\
\hline
\end{tabular}

$\mathrm{CCM}$ - corn cob mix, PDIE - protein supplied when energy is limited in the rumen, PDIN - protein supplied when nitrogen is limited in the rumen

$(\mathrm{C} / \mathrm{T})$ is located at position 204 of the fragment. Genotypes were determined based on the sequence.

Blood serum samples preparation

Blood samples of all bulls in three experimental groups were collected from vena jugularis externa between 8.00 and $9.30 \mathrm{~h}$. Blood was sampled into the test tube with silicon gel separator and coagulation accelerator (Dispolab, Czech Republic). Blood samples were centrifuged for $10 \mathrm{~min}\left(4^{\circ} \mathrm{C}, 2000 \mathrm{~g}\right)$ and the separated serum was stored at $-20^{\circ} \mathrm{C}$ until analyzed. Blood sampling was performed randomly in all bulls kept in individual groups.

Trace element analysis

Copper $(\mathrm{Cu})$, Iron $(\mathrm{Fe})$ and zinc $(\mathrm{Zn})$ serum concentration in serum were analysed on Konelab T20xt automatic analyser (Thermo Fisher Scientific, Finland) using currently available commercial kits (Biovendor-Laboratorni medicina, Czech Republic).

Statistical analysis

Changes in serum leptin and trace elements were analyzed by one-way ANOVA for factors leptin genotype.

\section{Leptin genotype analysis}

Blood sampling for leptin genotypes at the same time between 8.00 and $9.30 \mathrm{~h}$ In all bulls, $2 \mathrm{ml}$ of blood were collected from vena jugularis externa into tubes with ethylenediaminetetraacetic acid (EDTA). Blood was stored at $-20{ }^{\circ} \mathrm{C}$. Genomic DNA was isolated from blood using the QIAamp DNA Blood Mini Kit (Qiagen Inc., Valencia, CA, USA). The quality of DNA was verified by agarose gel electrophoresis in $1 \%$ gel visualized with ethidium bromide. Genotypes gene (transition $\mathrm{C} \rightarrow \mathrm{T}$ ) (Buchanan et al. 2002). For testing, we used our own methodology. PCR primers were designed based on GenBank U50365 sequence (FW: 5'TCGTTGTTATCCGCATCTGA 3', REV: 'TACCGTGTGTGAGATGTCATTG 3').

The PCR was performed in $12.5 \mu \mathrm{l}$ volumes HotStarTaq Master Mix (Qiagen) and 0.2 M of each forward and reverse primer. A PCR thermal profile consisted of pre-denaturation at $95{ }^{\circ} \mathrm{C}$ for 2 min followed by 30 cycles of denaturation at $95{ }^{\circ} \mathrm{C}$ for $30 \mathrm{~s}$, annealing temperature $56{ }^{\circ} \mathrm{C}$ for $30 \mathrm{~s}$, elongation at 72 ${ }^{\circ} \mathrm{C}$ for $30 \mathrm{~s}$ and final extension at $72{ }^{\circ} \mathrm{C}$ for $7 \mathrm{~min}$. The obtained PCR products of $278 \mathrm{bp}$ in size were verified on $3 \%$ agarose gel and resequenced using the ABI PRISM 3100-Avant Genetic Analyzer. The polymorphic locus 
ANOVA was followed by post-hoc Fischer LSD test. All statistical analyses were performed by Statistica 8.0 statistical software (StatSoft Inc., Tulsa, USA). Data presented mean \pm SE. The overall level of significance was defined as $P<0.05$.

\section{Results}

Based on the results of one-way ANOVA, significant effect of leptin genotype on zinc blood serum concentration $[\mathrm{F}(2,55)=6.138, P=0.019]$ was determined (Fig. 1). Using Fisher's LSD post-hoc test, significantly lower $(P<0.05)$ zinc concentration were recorded in bulls of TT group $\left(13.21 \pm 1.81 \mu \mathrm{mol} \cdot \mathrm{l}^{-1}\right)$ compared to $C C\left(20.09 \pm 1.11 \mu \mathrm{mol} \cdot \mathrm{l}^{-1}\right)$ and $C T$ group $\left(19.67 \pm 1.45 \mu \mathrm{mol} \cdot 1^{-1}\right)$. No significant effects of leptin genotype on copper $[\mathrm{F}(2,55)=0.571, P=0.094]$ and iron $[\mathrm{F}(2,55)=0.328, P=0.173]$ concentrations were found (Fig. 1).

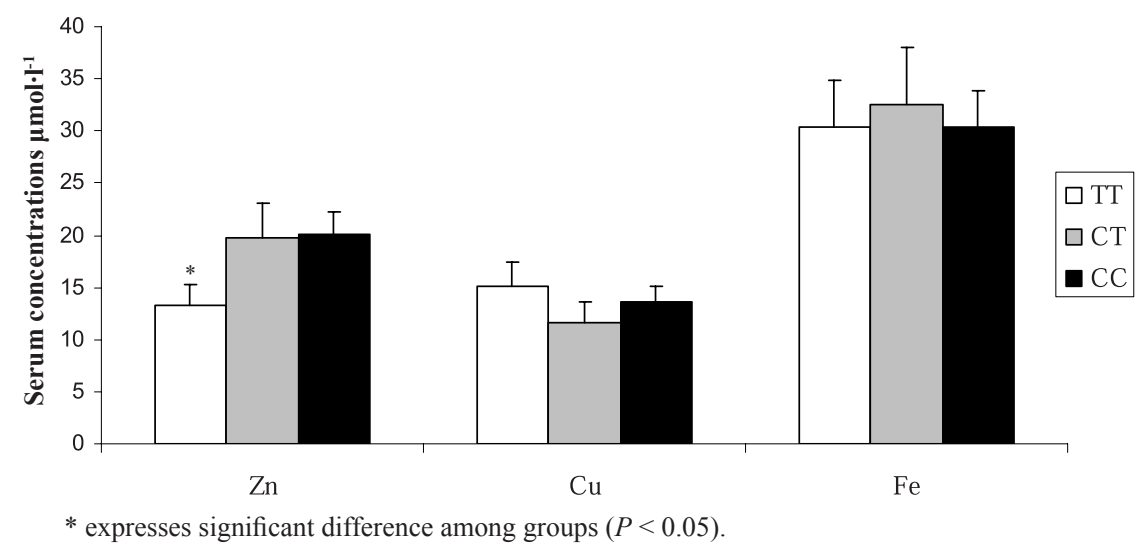

Fig. 1. Serum zinc, copper and iron concentration of 240 days old bulls divided into 3 groups depending on leptin single nucleotide polymorphism (TT, CT, CC).

\section{Discussion}

In several studies (Buchanan et al. 2002; Liefers et al. 2002), the T allele of leptin gene was associated with higher concentration of leptin in the blood of animals. Zinc and copper have been implicated in altered adipose metabolism and play important roles in many aspects of energy metabolism (Turnlund 1998). Based on this information, it might be expected that concentrations of serum trace elements would be different in bulls based on SNP of the leptin gene. In three groups of Czech Pied bulls we determined serum concentrations of copper, zinc and iron to be within the physiological range, similarly as in our previous studies (Pavlik et al. 2008, 2009, 2010). In the present study, we found a significant effect of SNP of the leptin gene on serum zinc concentration; however, not in the case of copper and iron concentrations. There are no studies aimed at assessing the relationship between trace elements and leptin in cattle. Micronutrients such as copper and zinc are possible mediators of leptin regulation in humans and rodents, although results are controversial (Mantzoros et al. 1998; Olusi et al. 2003). In humans, CasimiroLopes et al. (2009) noted a relationship between plasma zinc and leptin concentration only in males, a relationship between copper and leptin only in females, and suggested a sex-related difference on the leptin regulation by zinc and copper. Mantzoros et al. (1998) 
investigated the zinc status and its acting on plasma leptin concentrations and found a positive correlation between their levels. This association could be explained by the effect of zinc-alpha2-glycoprotein (ZAG) on leptin concentrations. Zinc-alpha2-glycoprotein is an adipokine involved in the metabolism of lipids in the adipocytes. Mammalian tissues have a high endogenous zinc content $\left(0.5-1.0 \mathrm{mmol} \cdot \mathrm{l}^{-1}\right)$ that is able to influence glucose metabolism. It is possible that the effect of zinc to increase leptin production may be associated with altered glucose metabolism but cannot be totally attributable to augmented lipogenesis (Chen et al. 2000). Some authors have reported that zinc might be a mediator of leptin production (Chen et al. 2000). However, Olusi et al. (2003) recorded no significant relationship between zinc and leptin in healthy adult human. Koury et al. (2007) reported that plasma leptin and trace elements were associated with exercising. Mantzoros et al. (1998) concluded that Zn may influence serum leptin concentrations, possibly by increasing the production of IL-2 and TNF- $\alpha$. Perrone et al. (1998) expected that copper could be linked to leptin regulation. Tajik and Nazifi (2011) also found no significant correlation of leptin with serum $\mathrm{Cu}$.

Increased leptin concentrations induced by cytokines such as interleukin-1 and tumour necrosis factor in experimental inflammatory situations have been claimed to be responsible for inflammation. Inflammation would elevate serum ferritin concentrations, thus disturbing its reliability in representing the labile-tissue iron content (Janik et al. 1997). The probable role of Fe in leptin metabolism is less well-defined. It was suggested that leptin may be involved in erythropoiesis (Nasri 2006). On the other hand, lack of association between plasma leptin concentrations and the degree of appetite was reported in iron deficient children (Topaloglu et al. 2001). However, Nasri (2006) and Tajik and Nazifi (2011) found no significant correlation between serum concentrations of leptin and iron.

In our study, the effects of single nucleotide polymorphism of the leptin gene were investigated. We found a significant effect of leptin SNP on serum zinc concentration but no effect of leptin SNP on other trace elements was recorded. The allele frequencies at SNP support a role in fat deposition, as shown by previous studies. Based on our results we may assume that zinc plays some role in the metabolism of adipose tissue, having an effect on beef quality.

\section{Acknowledgement}

The present study was supported by the project of National Agency for Agricultural Research Nr. QI 91A055 and the project of Ministry of Agriculture of the Czech Republic Nr. RO0312.

\section{References}

Buchanan FC, Fitzsimmons CJ, Van Kessel AG, Thue TD, Winkelman-Sim DC, Schmutz SM 2002: Association of a missense mutation in the bovine leptin gene with carcass fat content and leptin mRNA levels. Genet Sel Evol 34: 105-116

Casimiro-Lopes G, de Oliveira AV, Portella ES, Lisboa, PC, Donangelo CM, de Moura EG, Koury JC 2009: Plasma leptin, plasma zinc, and plasma copper are associated in elite female and male judo athletes. Biol Trace Elem Res 127: 109-115

Delavaud C, Ferlay A, Faulconnier Y, Bocquier F, Kann G, Chilliard Y 2002: Plasma leptin concentration in adult cattle: Effects of breed, adiposity, feeding level, and meal intake. J Anim Sci 80:1317-1328

Chen MD, Song YM, Lin PY. Zinc may be a mediator of leptin production in humans. Life Sci 66: 2143-2149

Janik JE, Curti BD, Considine RV, Rager HC, Powers GC, Alvord WG, Smith JW, Gause BL, Kopp WC 1997: Interleukin 1 alpha increases serum leptin concentrations in humans. J Clin Endocr Metab 82: 3084-3086

Koury JC, de Oliveira KDF, Lopes GC, de Oliveira AV, Portella ES, de Moura EG, Donangelo CM 2007: Plasma zinc, copper, leptin, and body composition are associated in elite female judo athletes. Biol Trace Elem Res 115: $23-30$

Li X, Ekerljung M, Lundstrom K, Lunden A 2013: Association of polymorphisms at DGAT1, leptin, SCD1, CAPN1 and CAST genes with color, marbling and water holding capacity in meat from beef cattle populations in Sweden. Meat Sci 94: 153-158 
Liefers SC, te Pas MFW, Veerkamp RF, van der Lende T 2002: Associations between leptin gene polymorphisms and production, live weight, energy balance, feed intake, and fertility in Holstein heifers. J Dairy Sci 85 : 1633-1638

Mantzoros CS, Prasad AS, Beck FWJ, Grabowski S, Kaplan J, Adair C, Brewer GJ 1998: Zinc may regulate serum leptin concentrations in humans. J Am Coll Nutr 17: 270-275

Nasri H 2006: Association of serum leptin with anemia in maintenance hemodialysis patients. Saudi J Kidney Dis Transpl 17: 521-525

Nkrumah JD, Li C, Basarab JB, Guercio S, Meng Y, Murdoch B, Hansen C, Moore SS 2004: Association of a single nucleotide polymorphism in the bovine leptin gene with feed intake, feed efficiency, growth, feeding behaviour, carcass quality and body composition. Can J Anim Sci 84: 211-219

Olusi S, Al-Awadhi A, Abiaka C, Abraham M, George S 2003: Serum copper levels and not zinc are positively associated with serum leptin concentrations in the healthy adult population. Biol Trace Elem Res 91: 137-144

Pavlik A, Filipcik R., Jelinek P, Bjelka M, Havlicek Z, Subrt J 2008: Indicators of the internal environment of beef cattle during fattening and their correlation to the quality of beef. Acta Vet Brno 77: 539-546

Pavlik A, Jelinek P, Matejicek M, Illek J 2009: Blood plasma metabolic profile of Aberdeen angus bulls during postnatal ontogenesis. Acta Vet Brno 79: 419-429

Pavlik A, Zahradkova R, Bures D, Jelinek P, Havlicek Z 2009: Indicators of the internal environment of gasconne calves during rearing. Acta Vet Brno 78: 37-45

Perrone L, Gialanella G, Moro R, Feng SL, Boccia E, Palombo G, Carbone MT, Di Toro R 1998: Zinc, copper and iron in obese children and adolescents. Nutr Res 18: 183-189

Stone RT, Kappes SM, Beattie CW 1996: The bovine homolog of the obese gene maps to Chromosome 4. Mamm Genome 7: 399-400

Tajik J, Nazifi S 2011: A study of correlation of serum leptin with trace elements in Water Buffalo (Bubalus bubalis). Pak Vet J 31: 231-234

Tallman DL, Taylor CG 2003: Effects of dietary fat and zinc on adiposity, serum leptin and adipose fatty acid composition in C57BL/6J mice. J Nutr Biochem 14: 17-23

Topaloglu AK, Hallioglu O, Canim A, Duzovali O, Yilgor E 2001: Lack of association between plasma leptin levels and appetite in children with iron deficiency Nutrition 17: 657-659

Turnlund JR 1998: Human whole-body copper metabolism. Am J Clin Nutr 67: 960S-964S 